\author{
S. Zinchenko ${ }^{1 *}$, A. Ben ${ }^{1}$, P. Nosov ${ }^{1}$, I. Popovych ${ }^{2}$, V. Mateichuk ${ }^{1}$, O. Grosheva ${ }^{1}$ \\ ${ }^{1}$ Kherson State Maritime Academy, Kherson, Ukraine; \\ ${ }^{2}$ Kherson State University, Kherson, Ukraine \\ (*E-mail:srz56@ukr.net)
}

\title{
The vessel movement optimisation with excessive control
}

\begin{abstract}
The article discusses the issues of automatic control of the vessel's movement using excessive control, which allows to organize the movement of the vessel without a drift angle, to reduce the hydrodynamic resistance and fuel consumption. Issues of reducing energy consumption and fuel economy on board, as well as related issues of reducing emissions and improving the environment are especially relevant at the present time. A brief review of literature devoted to improving the energy efficiency of ships was carried out. As a result of the analysis, it was found that the issues of improving energy efficiency are solved in various ways, for example, constructively, by reducing weight, hydrodynamic and aerodynamic drag of the hull, using a sail, creating more advanced power plants, however, the authors have not found methods and algorithms for reducing hydrodynamic drag and fuel consumption through the use of excessive control. It is concluded that the development of such systems is relevant. Mathematical, algorithmic, and software have been developed for an onboard controller simulator of a vessel's motion control system with excessive control, the operability and efficiency of which has been verified by numerical simulation in a closed circuit with a mathematical model of the control object for various types of vessels, navigation areas and weather conditions. The experiments have confirmed the efficiency and effectiveness of the developed method, algorithmic and software, and allow us to recommend them for practical use in the development of mathematical support for vessel control systems with excessive control.
\end{abstract}

Keywords: excessive control, sufficient control, optimal control, distribution of control, control quality criterion, minimization of fuel consumption.

\section{Introduction}

Issues of reducing energy and fuel consumption on board, as well as related issues of reducing emissions and improving the environment are especially relevant at present [1]. Ways to solve these issues are different, but most often these are constructive solutions to reduce weight [2], hydrodynamic [3], use a sail [4] or improve power plants. Fuel economy is also possible due to proper route planning, psychological preparation [5-7], the use of decision support systems (DSS) [8-12]. However, the presence of the human factor in both manual control systems and DSS systems excludes control optimization due to the impossibility of a quick and accurate assessment of the situation, the presence of delays in the transmission of information, tiredness and other factors. This article discusses the optimization of energy costs for moving a ship in automatic control systems through the use of sufficient or excessive control structures, organizing with their help the movement of the ship along a route without a drift angle, with less hydrodynamic resistance. In addition, redundant structures can further reduce energy costs for management due to the optimal redistribution of control within the structure itself. Traditionally, control redundancy is used to increase maneuverability, redundancy and reliability [13-15] and much less frequently for optimal control [16-19]. By control redundancy is understood the difference between the number of independent controls and the number of degrees of freedom to be controlled. In article [20], the authors analyzed the redundancy of control for some types of vessels for various purposes.

For most transport vessels, such as Bulk carrier 6 (Dis. 44081t), Crude Oil Tanker 4, Car Carrier 2 (Dis. 19587t), MSC container ship 1 (Dis. 32025t), Shuttle tanker 1 (Dis. 160529t), Container ship 22 (Dis. $191000 t$ ), River-sea ship 3 «Sormovsky», etc., the number of which is more than $85 \%$ of the total number of all vessels, the redundancy in the control at the transition is equal to $I U=U-S=-1$ (insufficient control), where $U=2$ is the number of independent control (power plant and aft steering wheel), and $S=3-$ the number of degrees of freedom to be controlled (longitudinal, lateral and angular movement in the yaw channel). On ships with insufficient control, the lateral effect of wind and current, as well as the moments from the effect of wind and current, can only be compensated by a corresponding turn of the vessel in the direction of external influence. But in this case, the ship will move with a drift angle, which increases the hydrodynamic resistance and fuel consumption. In the maneuvering mode, the Car Carrier 2 (Dis. 19587t), MSC con- 
tainer ship 1 (Dis. 32025t), Shuttle tanker 1 (Dis. 160529t) vessels have sufficient control $(I U=0)$ due to the additional use of the bow thruster.

Passenger ships Passenger cruise ship 10 Common DP, Passenger cruise ship 10 have redundancy at the transition $I U=5-3=2$, but in maneuverable mode $I U=7-3=4$. Offshore vessels OSV 11 , OSV 11 Common DP, OSV 11 Navis DP, OSV 11 AH, OSV 11 AH Common DP, OSV 11 AH Navis DP have redundancy at the transition $I U=4-3=1$, and in maneuverable mode $I U=6-3=3$.

The Semisubmersible 1AH, Semisubmersible 1AH Common, Semisubmersible 1AH Navis, Semisubmersible 1AH Common DP, Semisubmersible 1AH Navis DP oil platforms have redundancy in the transition and in maneuverable mode $I U=8-3=5$. For ships with sufficient and redundant control, the external influence from wind and current can be compensated by the total control vector so that the ship itself can move without a drift angle, with less hydrodynamic resistance and lower fuel consumption.

As can be seen in the examples of passenger, offshore vessels and oil platforms, control redundancy is usually used to increase maneuverability, as well as to increase reliability. In open sources, the authors were not able to find methods of using redundancy for control to reduce energy costs for moving the vessel. Therefore, the solution of this issue is an urgent scientific and technical problem.

The object of the research is the process of automatic vessel movement control with sufficient or excessive control structure, which allows to reduce energy costs for moving the vessel and save fuel by organizing the movement of the vessel without a drift angle.

The subject of the study is the methods and algorithms, implemented in the software of the onboard controller of the control system, and allowing to reduce energy costs for moving the vessel and save fuel.

The purpose of the Article is the development of methods and algorithms of automatic vessel movement control with sufficient or excessive control structure, which allows to reduce energy costs for moving the vessel and save fuel by organizing the movement of the vessel without a drift angle.

\section{Problem statement}

A mathematical model of a controlled object (own ship) is set in the form of a system of nonlinear differential equations

$$
\begin{gathered}
\frac{d \mathbf{X}}{d t}=\mathbf{f}(\mathbf{X}, \mathbf{U}, \mathbf{W}), \\
\mathbf{X}=\left(V_{x}, V_{y}, \omega_{z}, \psi, \Delta X, \Delta Y\right), \\
\mathbf{W}=\mathbf{f}_{w}(t),
\end{gathered}
$$

there $\mathbf{f}(\bullet)$ - mathematical model of the control object; $\mathbf{X}$ - state vector of the control object; $V_{x}, V_{y}, \omega_{z}, \psi, \Delta X, \Delta Y$ - components of the state vector, respectively, longitudinal speed, lateral speed, yaw rate, yaw angle, longitudinal and lateral displacement; $\mathbf{W}$ - vector of external influences from wind and current.

It is required to synthesize such control $\mathbf{U}(\mathbf{X})$ that would ensure minimum energy consumption and fuel consumption for moving the vessel in the presence of external influences $\mathbf{W}=\mathbf{f}_{w}(t)$.

\section{Literature review}

The article [2] presents research to reduce energy consumption and increase the environmental friendliness of a vessel by reducing the weight of a ship's structure made of fiber-reinforced plastic. A method was proposed for optimizing the weight of a structure, based on the algorithm of an artificial bee colony. The method was tested on the example of optimizing the design of a fishing vessel. The simulation results showed the possibility of reducing the weight of the structure by $8.31 \%$.

In article [3] there were considered the issues of improving the resistance characteristics and the quality of the vessel's trail field due to the optimization of contours. A decrease in resistance is directly related to a decrease in energy consumption for moving a ship and a decrease in fuel consumption. The shape of the contours was optimized by selecting 9 design variables using numerical methods. Model tests of the optimized form showed that the resistance and quality of the track field of the vessel were improved by $1.59 \%$ and $17.8 \%$, respectively.

In article [4] there were considered issues of increasing the energy efficiency of a ship with a sail. The design of a rigid sail was optimized using the aerodynamic profile parameterization method and particle swarm optimization algorithm. The performance of optimized airfoil has been verified by multi-point theory, 
computational fluid dynamics examination, and energy efficiency design index calculation. The maximum lift-to-drag ratio of optimized airfoil has increased by $10 \%$ than that of the arc-shaped sail.

The work $[5,6]$ explores the issues of psychological training for skippers, which indirectly, through the application of good maritime practice, can also improve the management of the ship and fuel economy.

In article [7] there were conducted psychological studies during the training «Master Pilot» of active sailors in the training center of the Kherson State Maritime Academy. The training is aimed at improving the professional training of acting sailors, as well as improving communication skills between the captain and the pilot, which helps to optimize the management of the vessel.

In articles [8-12] there were investigated the issues of the influence of the human factor on the vessel control processes, as well as ways to reduce this effect through the use of decision support systems (DSS), Using DSS allows to control not only the parameters of the vessel's movement and the operation of the power plant, but also the psychological state of the skipper, who is on duty, to recognize critical situations in time and to generate an alarm.

A number of works are also devoted to optimization of control due to redundancy. Traditionally, control redundancy has been used to increase maneuverability and reliability. However, both indirectly optimize control processes and also lead to lower energy costs.

So, in article [13] there were considered the issues of software control of reserving an attack submarine of the US Navy Sea Wolf. Policies and procedures for detecting and isolating faults, as well as reconfiguring equipment, are discussed.

In article [14] there are studied the influence of excess control on the power and vibration of the main axis of the rotor of a helicopter. By changing the rotor speed and the differential transverse step, which are redundant controls, it was possible to determine the state of low power and low vibration.

In article [15] there is described a fault-tolerant control method that minimizes the influence of error due to a change in the system control law when a failure is detected. The method evaluates the state of the system using analytical relationships, which allows to calculate faulty states of the system without using an observer.

In article [16] there was studied the distribution of the thrust force of an autonomous underwater vehicle engine between an excess number of propulsors using the presented redundancy resolution scheme. At the same time, an excessive number of propulsors was also used to increase the reliability of the system as a whole due to parry failures. The results are confirmed by computer simulation.

In article [17], the author considers the control of the angular position of the spacecraft using the excess structure of power gyroscopes. The presence of redundancy allows not only to increase the reliability of actuators as a whole, but also to optimize control in accordance with the selected quality function.

In article [18] there were considered the issues of controlling the unloading of flywheels of a control system for the angular orientation of a spacecraft. For a minimally redundant system of flywheels and electromagnetic executive equipment of the unloading system that create an additional external moment, control algorithms are synthesized that guarantee asymptotic stability to the zero solution of model equations describing the movement of the flywheels. The operability of the proposed algorithms and the features of the unloading process are investigated by the example of the controlled motion of a spacecraft while stabilizing the triaxial orbital orientation.

In article [19] there was considered the use of angular redundancy for planning and optimizing the path of movement of a welding torch in various complex media. Efficiency strategies have been introduced, such as a heuristic domain sampling strategy, a collision verification strategy. The proposed algorithm is effective in solving complex planning problems when the weld passes in tight places. The experiment confirmed that the algorithm proposed by the authors can not only find a path free from collisions with obstacles in various complex environments, but also optimize the angle of the welding torch according to the established criterion.

\section{Material and method}

Expand system (1) in the vicinity of the equilibrium state point for two control schemes $\mathbf{U}=\left(\theta, \delta_{1}\right)$ (insufficient control) and $\mathbf{U}=\left(\theta, \delta_{1}, \delta_{2}, \ldots \delta_{n}\right)$ (excessive control). 
For a circuit with insufficient control, system (1) takes the form

$$
\begin{gathered}
\left(m+\lambda_{11}\right) \frac{d V_{x}}{d t}=\frac{d P}{d \theta} \theta-\frac{d F_{x}}{d V_{x}} V_{x}-\frac{d F_{x}}{d \beta} \beta-\frac{d F_{x}}{d \delta_{1}} \delta_{1}+W_{x}, \\
\left(m+\lambda_{22}\right) \frac{d V_{y}}{d t}=\frac{d F_{y}}{d \theta} \theta-\frac{d F_{y}}{d V_{y}} V_{y}+\frac{d F_{y}}{d \beta} \beta+\frac{d F_{y}}{d \delta_{1}} \delta_{1}+W_{y}, \\
\left(I_{z}+\lambda_{66}\right) \frac{d \omega_{z}}{d t}=\frac{d F_{y}}{d \theta} l \theta-\frac{d M_{z}}{d \omega_{z}} \omega_{z}+\frac{d F_{y}}{d \delta_{1}} \delta_{1} l+\frac{d M_{z}}{d \beta} \beta+W_{z} . \\
\frac{d \psi}{d t}=\omega_{z}, \frac{d \Delta X}{d t}=V_{x}, \frac{d \Delta Y}{d t}=V_{y},
\end{gathered}
$$

For a scheme with redundant control $\mathbf{U}=\left(\theta, \delta_{1}, \delta_{2}, \ldots \delta_{n}\right)$, system (1) takes the form

$$
\begin{gathered}
\left(m+\lambda_{11}\right) \frac{d V_{x}}{d t}=\frac{d P}{d \theta} \theta-\frac{d F_{x}}{d V_{x}} V_{x}-\frac{d F_{x}}{d \beta} \beta-\frac{d F_{x}}{d \delta_{1}} \delta_{1}-\frac{d F_{x}}{d \delta_{2}} \delta_{2}-\ldots-\frac{d F_{x}}{d \delta_{n}} \delta_{n}+W_{x}, \\
\left(m+\lambda_{22}\right) \frac{d V_{y}}{d t}=\frac{d F_{y}}{d \theta} \theta-\frac{d F_{y}}{d V_{y}} V_{y}+\frac{d F_{y}}{d \beta} \beta+\frac{d F_{y}}{d \delta_{1}} \delta_{1}+\frac{d F_{y}}{d \delta_{2}} \delta_{2}+\ldots+\frac{d F_{y}}{d \delta_{n}} \delta_{n}+W_{y}, \\
\left(I_{z}+\lambda_{66}\right) \frac{d \omega_{z}}{d t}=\frac{d F_{y}}{d \theta} l \theta-\frac{d M_{z}}{d \omega_{z}} \omega_{z}+\frac{d F_{y}}{d \delta_{1}} \delta_{1} l_{1}+\frac{d F_{y}}{d \delta_{2}} \delta_{2} l_{2}+\ldots+\frac{d F_{y}}{d \delta_{n}} \delta_{n} l_{n}+\frac{d M_{z}}{d \beta} \beta+W_{z}, \\
\frac{d \psi}{d t}=\omega_{z}, \frac{d \Delta X}{d t}=V_{x}, \frac{d \Delta Y}{d t}=V_{y},
\end{gathered}
$$

where $m$ - vessel mass; $I_{z}$ - Inertia moment of the vessel; $\lambda_{11} \lambda_{22} \lambda_{66}$ - attached masses of water; $\frac{d F_{x}}{d V_{x}}, \frac{d F_{x}}{d \beta}, \frac{d F_{y}}{d V_{y}}, \frac{d F_{y}}{d \beta}, \frac{d M_{z}}{d \omega_{z}}, \frac{d M_{z}}{d \beta}-$ hydrodynamic characteristics of the vessel; $\frac{d P}{d \theta}, \frac{d F_{x}}{d \delta_{1}}, \frac{d F_{x}}{d \delta_{2}}, \ldots$, $\frac{d F_{x}}{d \delta_{n}}, \frac{d F_{y}}{d \theta}, \frac{d F_{y}}{d \delta_{1}}, \frac{d F_{y}}{d \delta_{2}}, \ldots, \frac{d F_{y}}{d \delta_{n}}-$ control characteristics of the vessel; $\theta, \beta, \delta_{1}, \delta_{2}, \ldots, \delta_{n}$ - telegraph deflection angle, drift angle and steering angles; $l, l_{1}, l_{2}, \ldots l_{n}$ — arms from the propeller and rudders to the center of rotation; $P$ - screw force; $\mathbf{W}=\left(W_{x}, W_{y}, W_{z}\right)$ - components of external influences of wind and current.

For steady state $\left(\frac{d V_{x}}{d t}=0, \frac{d V_{y}}{d t}=0, \frac{d \omega_{z}}{d t}=0, \frac{d \psi}{d t}=0, \frac{d \Delta X}{d t}=0, \frac{d \Delta Y}{d t}=0\right)$ the system of equations

takes the form

$$
\begin{gathered}
\frac{d F_{x}}{d V_{x}} V_{x}=\frac{d P}{d \theta} \theta-\frac{d F_{x}}{d \beta} \beta-\frac{d F_{x}}{d \delta_{1}} \delta_{1}+W_{x}, \\
\frac{d F_{y}}{d \beta} \beta+\frac{d F_{y}}{d \delta_{1}} \delta_{1}=-\frac{d F_{y}}{d \theta} \theta-W_{y}, \\
\frac{d M_{z}}{d \beta} \beta-\frac{d F_{y}}{d \delta_{1}} l \delta_{1}=-\frac{d F_{y}}{d \theta} l \theta-W_{z}, \\
\psi=\text { const, } V_{x}=\text { const, } V_{y}=\text { const } .
\end{gathered}
$$

From the second and third equations of system (4) it follows that in the steady state, in the presence of external influences from the wind and the current, the drift angle and the rudder angle are not equal to zero $\left(\beta \neq 0, \delta_{1} \neq 0\right)$. Moreover, due to the presence of lateral force and the moment from the rotation of the screw, which are also disturbances, even in the absence of external influences from wind and current, the drift angle and the rudder angle will also not be zero.

For steady state $\left(\frac{d V_{x}}{d t}=0, \frac{d V_{y}}{d t}=0, \frac{d \omega_{z}}{d t}=0, \frac{d \psi}{d t}=0, \frac{d \Delta X}{d t}=0, \frac{d \Delta Y}{d t}=0\right)$ the system of equations takes the form 


$$
\begin{gathered}
\frac{d F_{x}}{d V_{x}} V_{x}=\frac{d P}{d \theta} \theta-\frac{d F_{x}}{d \beta} \beta-\frac{d F_{x}}{d \delta_{1}} \delta_{1}-\frac{d F_{x}}{d \delta_{2}} \delta_{2}-\ldots-\frac{d F_{x}}{d \delta_{n}} \delta_{n}+W_{x}, \\
\frac{d F_{y}}{d \beta} \beta+\frac{d F_{y}}{d \delta_{1}} \delta_{1}+\frac{d F_{y}}{d \delta_{2}} \delta_{2}+\ldots+\frac{d F_{y}}{d \delta_{n}} \delta_{n}=-\frac{d F_{y}}{d \theta} \theta-W_{y}, \\
\frac{d M_{z}}{d \beta} \beta+\frac{d F_{y}}{d \delta_{1}} l_{1} \delta_{1}+\frac{d F_{y}}{d \delta_{2}} l_{2} \delta_{2}+\ldots+\frac{d F_{y}}{d \delta_{n}} l_{n} \delta_{n}=-\frac{d F_{y}}{d \theta} l \theta-W_{z}, \\
\psi=\text { const, } V_{x}=\text { const, } V_{y}=\text { const . }
\end{gathered}
$$

From the second and third equations of system (5) it follows that the drift angle can be reduced to zero even in the presence of external influences from wind, current and screw due to the appropriate choice of controls $\mathbf{U}=\left(\theta, \delta_{1}, \delta_{2}, \ldots \delta_{n}\right)$. At the same time, the minimum required number of independent controls that can provide a zero drift angle of the vessel is $2, \mathbf{U}=\left(\theta, \delta_{1}, \delta_{2}\right)$.
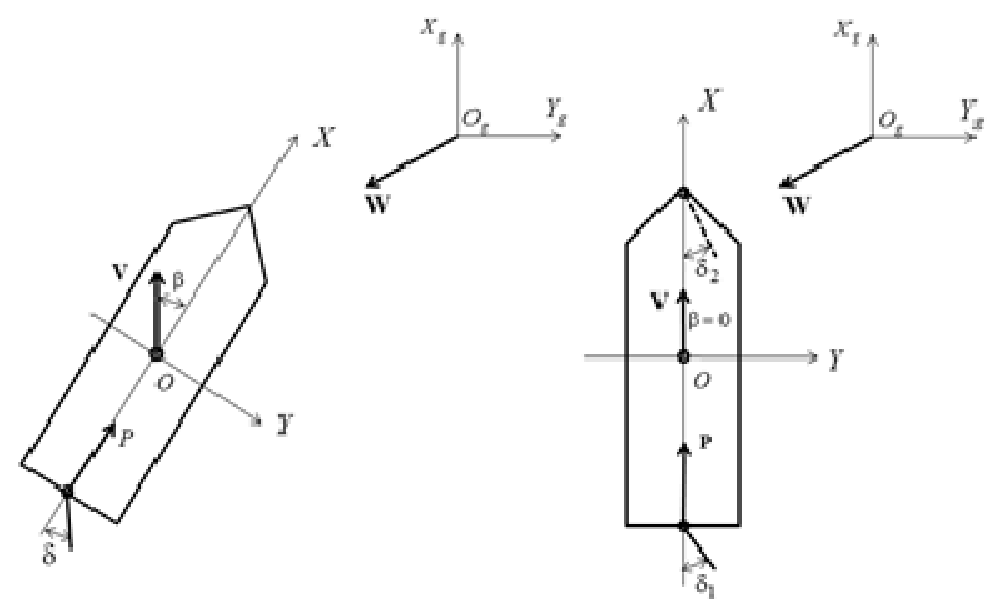

Figure 1. Steady state of ships with insufficient and sufficient control under external influences from wind and current

Thus, in contrast to the control circuit (4), which cannot ensure the movement of the vessel without a drift angle in the presence (and even in the absence) of external disturbances from wind and current, the control circuit (5) allows to control the vessel without a drift angle by compensating for external disturbances by the controls. The absence of a drift angle reduces the hydrodynamic resistance to the movement of the vessel, reduces fuel consumption and reduces emissions.

Figure 1 shows the steady state of ships with insufficient $\mathbf{U}=\left(\theta, \delta_{1}\right)$ and sufficient $\mathbf{U}=\left(\theta, \delta_{1}, \delta_{2}\right)$ control under external influences from wind and current.

To bring the control object to state (5) with a zero drift angle, we use the PID controller and the subsequent splitting of the control into two controls $\mathbf{U}=\left(\delta_{1}, \delta_{2}\right)[20]$.

$$
\begin{gathered}
\theta=V_{x}^{*} \frac{\pi}{2 V_{\max }}, \\
\sigma_{1}=k_{y} V_{y}+k_{y} \Delta Y+k_{\int y} \int \Delta Y d t, \\
\sigma_{2}=k_{\omega} \omega_{z}+k_{\psi} \psi+k_{\int \psi} \int \psi d t, \\
\delta_{1}=\sigma_{1}-\sigma_{2}, \\
\delta_{2}=-\sigma_{1}-\sigma_{2},
\end{gathered}
$$

where $V_{x}^{*}, V_{\max }$ - respectively, the required and maximum speed of the vessel; $k_{y}, k_{y}, k_{\int y}, k_{\omega}, k_{\psi}, k_{\int_{\psi}}-\mathrm{PID}$ gain. 


\section{Experements}

To test the operability and effectiveness of the method and algorithms for controlling ship schemes with sufficient and excessive control (3), comparing them with the traditional scheme with insufficient control (2), mathematical modeling of the vessel motion in a closed circuit with a control system was carried out.

For the scheme (3), the control and splitting law (6) was used, and for the scheme (2) the control law (7) was used

$$
\begin{gathered}
\theta=V_{x}^{*} \frac{\pi}{2 V_{\max }}, \\
\sigma_{1}=k_{y} V_{y}+k_{y} \Delta Y+k_{\int y} \int \Delta Y d t, \\
\delta_{1}=\sigma_{1} .
\end{gathered}
$$

The results of mathematical modeling are presented in the form of time variation graphs of the longitudinal velocity $\left(V_{x g}\right)$, lateral velocity $\left(V_{y g}\right)$, yaw rate $\left(W_{z}\right)$, course $\left(F_{i}\right)$, longitudinal displacement $\left(X_{g}\right)$, lateral displacement $\left(Y_{g}\right)$, telegraph deflection angle (teta), rudder deflection angles (delta1, delta2).

Figure 2 shows the results of mathematical modeling of a control circuit $\mathbf{U}=\left(\theta, \delta_{1}\right)$ with control (7) for the values of the lateral component of wind speed and current $W=(1,2,3,3.5) \mathrm{m} / \mathrm{s}$. A further increase in the lateral component of wind speed and current leads to loss of control. As can be seen from the above graphs, control (7) ensures that the vessel is kept on the route (lateral mismatch and lateral mismatch speed is reduced to zero), however, the course $\left(F_{i}\right)$ differs from the required value $\left(F_{i}=0\right)$ by the drift angle, which in this case, for the maximum lateral component of wind speed and current $W=3.5 \mathrm{~m} / \mathrm{s}$, it is $4^{\circ}$.
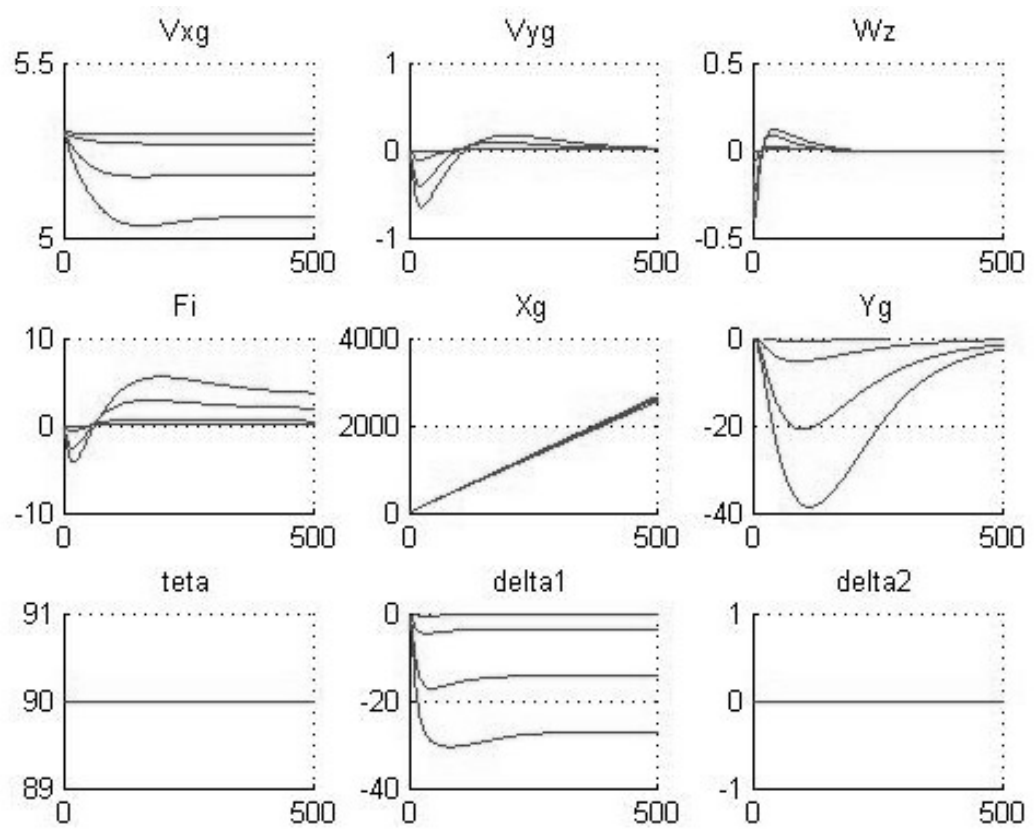

Figure 2. Results of mathematical modeling of the vessel movement with insufficient control

Figure 3 shows the results of mathematical modeling of a control circuit with control (6) for the values of the lateral component of wind speed and current $=(1,2,3,4,4.5) \mathrm{m} / \mathrm{s}$. A further increase in the lateral component of wind speed and current leads to loss of control. As can be seen from the above graphs, control (6) provides not only the retention of the vessel along the route (lateral mismatch and lateral mismatch speed is reduced to zero), but also maintaining a given course $\left(F_{i}=0\right)$ with a zero drift angle. 

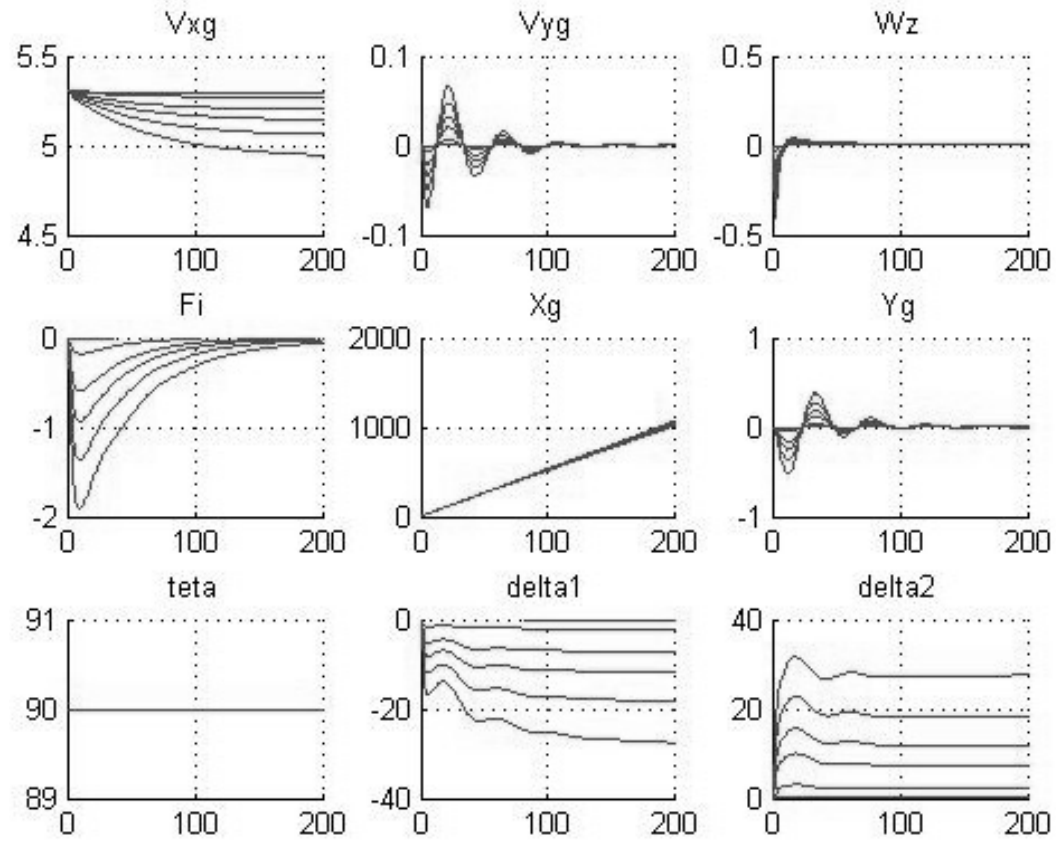

Figure 3. Results of mathematical modeling of the vessel movement with sufficient control

In addition, from the above results of mathematical modeling it also follows that the control circuit with control (6) is able to maintain control for large values of the lateral component of wind speed and current, transient processes in this control circuit also pass 5 times faster.

Table 1 shows the fuel consumption $[\mathrm{kg}]$ per $5 \mathrm{~km}$ of track for two control schemes.

Ta b l e 1

\section{Fuel consumption [ $\mathrm{kg}]$ per $5 \mathrm{~km}$ of track for two control schemes}

\begin{tabular}{|c|c|c|}
\hline Control scheme & Lateral wind speed $[\mathrm{m} / \mathrm{s}]$ & Fuel consumption $[\mathrm{kg}] \mathrm{per} 5 \mathrm{~km}$ \\
\hline \multirow{4}{*}{ The scheme $\mathbf{U}=\left(\theta, \delta_{1}\right)$} & 1 & 63,89 \\
\cline { 2 - 3 } & 2 & 64.227 \\
\cline { 2 - 3 } & 3 & 65.310 \\
\cline { 2 - 3 } & 3.5 & 66.826 \\
\cline { 2 - 3 } & 4 & The system is not controllable \\
\hline \multirow{4}{*}{ The scheme $\mathbf{U}=\left(\theta, \delta_{1}, \delta_{2}\right)$} & 1 & 63.89 \\
\cline { 2 - 3 } & 2 & 64.200 \\
\cline { 2 - 3 } & 3 & 65.012 \\
\cline { 2 - 3 } & 3.5 & 65.716 \\
\cline { 2 - 3 } & 4 & 66.758 \\
\cline { 2 - 3 } & 4.5 & 68.315 \\
\cline { 2 - 3 } & 5 & The system is not controllable \\
\hline
\end{tabular}

As follows from the presented results of comparing fuel consumption, the circuit $\mathbf{U}=\left(\theta, \delta_{1}, \delta_{2}\right)$ is more economical than the circuit $\mathbf{U}=\left(\theta, \delta_{1}\right)$. So, for the same lateral component of wind speed $W=3.5 \mathrm{~m} / \mathrm{s}$, the circuit $\mathbf{U}=\left(\theta, \delta_{1}, \delta_{2}\right)$ consumes $1.111 \mathrm{~kg}$ less fuel for every $5 \mathrm{~km}$ of the track. With an increase in the lateral component of wind speed, fuel economy also increases.

From the above simulation results, it can be seen that in the presence of external influences:

- transition processes in scheme with sufficient control proceed several times faster than in scheme with insufficient control;

- the scheme with insufficient control ensures that the vessel is kept on the route, but does not provide a zero drift angle; 
- the scheme with sufficient control ensures the retention of the vessel on the route with a zero drift angle;

- the scheme with sufficient control provides control for higher values of crosswind than a scheme with insufficient control;

- the scheme with sufficient control is more economical in comparison with the scheme with insufficient control; the amount of fuel saved increases with increasing lateral component of the wind speed;

- the scheme with sufficient control is more reliable due to redundancy of control channels.

\section{Conclusions}

There were proposed a method and algorithm for controlling a vessel with a sufficient and redundant control scheme, which allows to reduce fuel consumption at the transition by providing movement with a zero drift angle.

The scientific novelty of the results obtained is that for the first time a method and algorithms are proposed that provide fuel economy during the transition due to the organization of the movement of the vessel with a zero drift angle in the presence of transverse components of the external effects of wind and current. This is achieved through the use of ship control circuits with sufficient or excessive control, periodic, with the on-board controller clock cycle, measuring the parameters of the vessel's movement in the channels of longitudinal, lateral and angular movement, calculating the deviation of the measured parameters from their program values, and forming using the PID controller control signals in the channels of longitudinal, lateral and angular movement, splitting the received control signals into control of individual actuating control structures.

The practical value of the obtained results lies in the fact that the developed method and algorithms are implemented in the control system software and investigated in a closed circuit with the control object by numerical simulation in the MATLAB environment for various types of vessels, navigation areas and weather conditions.

Further research will be related to the development of a method and algorithms for control redundant structures with optimization of the quality control function.

\section{Acknowledgements}

The work was carried out in the framework of the research «Development of software solutions for dynamic functions of dynamically positioning systems of marine vessels», (state registration number 0119U100948), Department of Navigation and Electronic Navigation Systems of Kherson State Maritime Academy.

\section{References}

1 Vidoza J.A. Design and optimization of power hubs for Brazilian off-shore oil production units / J.A. Vidoza, J.G. Andreasen, F. Haglind, M. Reis, W. Gallo // Energy. - 2019. - Vol. 176, No. 1. - P. 656-666. DOI: 10.1016/j.energy.2019.04.022

2 Kai L. Research on structural optimization method of FRP fishing vessel based on artificial bee colony algorithm / L. Kai, Y. Yanyun, W. Yunlong, H. Zhenwu // Advances in Engineering Software. - 2018. Vol. 121. - P. 250-261. DOI: 10.1016/j.advengsoft.2018.03.011

3 Feng Y. Multidisciplinary optimization of an offshore aquaculture vessel hull form based on the support vector regression surrogate model / Y. Feng, Z. Chen, Y. Dai, F. Wang, J. Cai, Z. Shen // Ocean Engineering. — 2018. — Vol. 166. — P. $145-158$. DOI: $10.1016 /$ j.oceaneng.2018.07.062

4 Ma Y. Hard sail optimization and energy efficiency enhancement for sail-assisted vessel / Y. Ma, H. Bi, M. Hu, Y. Zheng, L. Gan // Ocean Engineering. — 2019. — Vol. 173, No. 1. - P. 687-699. DOI: 10.1016/j.oceaneng.2019.01.026

5 Popovych I.S. Research of Relationship between the Social Expectations and Professional Training of Lyceum Students studying in the Field of Shipbuilding / I.S. Popovych, O.Ye. Blynova, M.I. Aleksieieva, P.S. Nosov, N.Ye. Zavatska, O.O. Smyrnova // Revista Espacios. - 2019. - Vol. 40, No. 33. - P. 21-34.

6 Popovych I. Constructing a Structural-Functional Model of Social Expectations of the Personality [E-Reader Version] / I. Popovych, A. Borysiuk, L. Zahrai, O. Fedoruk, P. Nosov, S. Zinchenko, V. Mateichuk // Revista Inclusiones. — 2020. — 7-num Especial. - P. 154-167. - Retrieved from http://ekhsuir.kspu.edu/handle/123456789/10471

7 Popovych I.S. Experimental Research of Effective «The Ship's Captain and the Pilot» Interaction Formation by Means of Training Technologies / I.S. Popovych, V.V. Cherniavskyi, S.V. Dudchenko, S.M. Zinchenko, P.S. Nosov, O.O. Yevdokimova, O.O. Burak, V.M. Mateichuk // Revista Espascios. - 2020. - Vol. 41, No.11. - P.30. - Retrieved from http://www.revistaespacios.com/a20v41n11/20411130.html 
8 Nosov P.S. Diagnostic system of perception of navigation danger when implementation complicated maneuvers / P.S. Nosov, S.M. Zinchenko, I.S. Popovych, A.P. Ben, Y.A. Nahrybelnyi, V.M. Mateichuk // Radio Electronics, Computer Science, Control. 2020. - No. 1. - P. 146-161.

9 Nosov P.S. Identification of «Human error» negative manifestation in maritime transport / P.S. Nosov, A.P. Ben, V.N. Matejchuk, M.S. Safonov // Radio Electronics, Computer Science, Control. — 2018. — Vol. 4, No. 47. — P. 204-213. DOI: 10.15588/1607-3274-2018-4-20.

10 Nosov P. Approaches going to determination periods of the human factor of navigators during supernumerary situations / P. Nosov, A. Ben, A. Safonova, I. Palamarchuk // Radio Electronics, Computer Science, Control. — 2019. — Vol. 2, No. 49. P. 140-150. DOI: 10.15588/1607-3274-2019-2-15

11 Nosov P. Development of means for experimental identification of navigator attention in ergatic systems of maritime transport / P. Nosov, I. Palamarchuk, S. Zinchenko, I. Popovych, Y. Nahrybelnyi, H. Nosova // Bulletin of the University of Karaganda - Physics. — 2020. — No. 1(97). - P. 58-69. DOI: 10.31489/2020Ph1/58-69

12 Zinchenko S.M. Automatic collision avoidance system with multiple targets, including maneuvering ones / S.M. Zinchenko, P.S. Nosov, V.M. Mateichuk, P.P. Mamenko, I.S. Popovych, O.O. Grosheva // Bulletin of the University of Karaganda - Physics. 2019. — No. 4(96). — P. 69-79. DOI: 10.31489/2019Ph4/69-79

13 Sims J.T. Redundancy management software services for Seawolf ship control system / J.T. Sims // Proceedings of IEEE 27th International Symposium on Fault Tolerant Computing. — 1997, June. DOI: 10.1109/FTCS.1997.614114.

14 Jacobellis G. Using Control Redundancy for Power and Vibration Reduction on a Coaxial Rotor Helicopter at High Speeds / G. Jacobellis, F. Gandhi, M. Floros // Journal of the American Helicopter Society. — 2019. - Vol. 64, No. 3. - P. 1-15. DOI: 10.4050/JAHS.64.032008

15 Mohammadi A. An Active Actuator Fault-Tolerant Control of a Quadrotor Based on Analytical Redundancy Relations / A. Mohammadi, A. Ramezani // Iranian journal of science and technology — transactions of electrical engineering. - 2020. Vol. 44. — P. 1069-1079. DOI: 10.1007/s40998-019-00292-6

16 Tarun K.P. Fault-tolerant control of an autonomous underwater vehicle under thruster redundancy / K.P. Tarun, S. Nilanjan // Robotics and Autonomous Systems. - 2001. - Vol. 34, No. 1. - P. 39-52.

17 Земляков А.С. Управление угловым положением космического аппарата с избыточной структурой гиродинов / А.С. Земляков // Вестн. Казан. гос. техн. ун-та им. А.Н. Туполева. — 2001. - Т. 4. — С. 56-62.

18 Lebedev D.V. Momentum unloading excessive reaction-wheel system of a spacecraft / D.V. Lebedev // Journal of Computer and Systems Sciences International. - 2008. - Vol. 47, No. 4. - P. 613-620.

19 Wenxiang G. Automatic motion planning for complex welding problems by considering angular redundancy / G. Wenxiang, T. Qing, Y. Jin, Y. Yaru // Robotics and Computer-Integrated Manufacturing. — 2020. — P. 62. DOI: 10.1016/j.rcim.2019.101862

20 Zinchenko S.M. Control redundancy as a quantitative measure of ship maneuverability / S.M. Zinchenko, P.S. Nosov, P.P. Mamenko, O.O. Grosheva, V.M. Matejchuk // Advanced Information and Innovative Technologies for Transport (MINT 2019): Materials of the XII International Scientific and Practical Conference. - Kherson State Maritime Academy, Kherson, Ukraine, 2019, May. - P. 97-99.

\title{
С. Зинченко, А. Бень, П. Носов, И. Попович, В. Матейчук, О. Грошева
}

\section{Кеме қозғалысын шамадан тыс басқаруды оңтайландыру}

\begin{abstract}
Мақалада шамадан тыс басқару көмегімен кеменің қозғалысын автоматты түрде басқару, гидродинамикалық кедергі мен отын шығынын азайту, кеменің қозғалысын көлбеу бұрышсыз ұйымдастыруға мүмкіндік беретін мәселелер талқыланған. Қазіргі уақытта бортта энергия тұтынуды және отын үнемдеуді азайту мәселелері, сондай-ақ шығарындыларды азайту және қоршаған ортаны жақсарту мәселелері өзекті болып отыр. Кемелердің энергия тиімділігін арттыруға арналған әдебиеттерге қысқаша шолу жасалған. Талдау нәтижесінде энергия тиімділігін арттыру мәселелері әртүрлі жолдармен шешілетіні, мысалы, корпустың салмағы, гидродинамикалық және аэродинамикалық сүйреуі, парусты пайдалану, дамыған электр станцияларын құру, алайда авторлар гидродинамикалық сүйреу мен отын шығынын шамадан тыс бақылауды азайту әдістері мен алгоритмдерін тапқан жоқ. Мұндай жүйелердің дамуы өзекті болып табылады. Шамадан тыс бақылауы бар кеменің қозғалысын басқару жүйесінің борттық контроллері үшін математикалық, алгоритмдік және бағдарламалық жасақтама жасалды, оның жұмыс қабілеттілігі және тиімділігі басқару объектісінің математикалық моделімен жабық тізбектегі сандық модельдеумен тексерілді, кемелердің әртүрлі түрлеріне, навигациялық аймақтарға және ауа-райына байланысты жүргізілген тәжірибелер әзірленген әдістің, алгоритмдік және бағдарламалық жасақтаманың жұмысқа қабілеттілігі мен тиімділігін растады және оларды шамадан тыс басқарумен кеменің басқару жүйелеріне математикалық қолдау жасауда практикалық қолдануға ұсынуға мүмкіндік береді.
\end{abstract}

Кілт сөздер: шамадан тыс бақылау, жеткілікті бақылау, оңтайлы бақылау, бақылауды бөлу, бақылау сапасының өлшемі, отын шығынын азайту. 


\title{
С. Зинченко, А. Бень, П. Носов, И. Попович, В. Матейчук, О. Грошева
}

\section{Оптимизация движения судна с избыточным управлением}

\begin{abstract}
В статье рассмотрены вопросы автоматического управления движением судна с использованием избыточного управления, что позволяет организовать движение судна без угла дрейфа, снизить гидродинамическое сопротивление и расход топлива. Вопросы сокращения энергопотребления и экономии топлива на борту, а также связанные с ними вопросы сокращения выбросов и улучшения состояния окружающей среды особенно актуальны в настоящее время. Проведен краткий обзор литературных источников, посвященных повышению энергоэффективности судов. В результате проведенного анализа выявлено, что вопросы повышения энергоэффективности решаются различными способами, например, конструктивно, путем снижения веса, гидродинамического и аэродинамического сопротивления корпуса, с помощью паруса, создания более совершенных силовых установок. Однако авторами не найдены методы и алгоритмы уменьшения гидродинамического сопротивления и расхода топлива за счет использования избыточного управления. Сделан вывод об актуальности разработки таких систем. Разработано математическое, алгоритмическое и программное обеспечение для имитатора бортового контроллера системы управления движением судна с избыточным управлением, работоспособность и эффективность которых проверена численным моделированием в замкнутой схеме с математической моделью объекта управления для различных типов судов, районов плавания и погодных условий. Проведенные эксперименты подтвердили работоспособность и эффективность разработанного метода, алгоритмического и программного обеспечения и позволяют рекомендовать их для практического использования при разработке математического обеспечения систем управления судами с избыточным управлением.
\end{abstract}

Ключевые слова: избыточное управление, достаточное управление, оптимальное управление, распределение управления, критерий качества управления, минимизация расхода топлива.

\section{References}

1 Vidoza, J.A., Andreasen, J.G., Haglind, F., Reis, M., \& Gallo, W. (2019). Design and optimization of power hubs for Brazilian off-shore oil production units. Energy, 176(1), 656-666. DOI: 10.1016/j.energy.2019.04.022

2 Kai, L., Yanyun, Y., Yunlong, W., \& Zhenwu, H. (2018). Research on structural optimization method of FRP fishing vessel based on artificial bee colony algorithm. Advances in Engineering Software, 121, 250-261. DOI: 10.1016/j.advengsoft.2018.03.011

3 Feng, Y., Chen, Z., Dai, Y., Wang, F., Cai, J., \& Shen, Z. (2018). Multidisciplinary optimization of an offshore aquaculture vessel hull form based on the support vector regression surrogate model. Ocean Engineering, 166, 145-158. DOI: 10.1016/j.oceaneng.2018.07.062

4 Ma, Y., Bi, H., Hu, M., Zheng, Y., \& Gan L. (2019). Hard sail optimization and energy efficiency enhancement for sailassisted vessel. Ocean Engineering, 173(1), 687-699. DOI: 10.1016/j.oceaneng.2019.01.026

5 Popovych, I.S., Blynova, O.Ye., Aleksieieva, M.I., Nosov, P.S., Zavatska, N.Ye., \& Smyrnova, O.O. (2019). Research of Relationship between the Social Expectations and Professional Training of Lyceum Students studying in the Field of Shipbuilding. Revista Espacios, 40(33), 21-34.

6 Popovych, I., Borysiuk, A., Zahrai, L., Fedoruk, O., Nosov, P., Zinchenko, S., \& Mateichuk, V. (2020). Constructing a Structural-Functional Model of Social Expectations of the Personality [E-Reader Version]. Revista Inclusiones, 7-num Especial, $154-167$. Retrieved from http://ekhsuir.kspu.edu/handle/123456789/10471

7 Popovych, I.S., Cherniavskyi, V.V., Dudchenko, S.V., Zinchenko, S.M., Nosov, P.S., \& Yevdokimova, O.O. et al. (2020). Experimental Research of Effective «The Ship's Captain and the Pilot» Interaction Formation by Means of Training Technologies. Revista Espascios, 41(11), 30. Retrieved from http://www.revistaespacios.com/a20v41n11/20411130.html

8 Nosov, P.S., Zinchenko, S.M., Popovych, I.S., Ben, A.P., Nahrybelnyi, Y.A., \& Mateichuk, V.M. (2020). Diagnostic system of perception of navigation danger when implementation complicated maneuvers. Radio Electronics, Computer Science, Control, 1 , $146-161$.

9 Nosov, P.S., Ben, A.P., Matejchuk, V.N., \& Safonov, M.S. (2018). Identification of «Human error» negative manifestation in maritime transport. Radio Electronics, Computer Science, Control, 4(47), 204-213. DOI: 10.15588/1607-3274-2018-4-20.

10 Nosov, P., Ben, A., Safonova, A., \& Palamarchuk, I. (2019). Approaches going to determination periods of the human factor of navigators during supernumerary situations. Radio Electronics, Computer Science, Control, 2(49), 140-150. DOI: 10.15588/1607-3274-2019-2-15

11 Nosov, P., Palamarchuk, I., Zinchenko, S., Popovych, I., Nahrybelnyi, Y., \& Nosova, H. (2020). Development of means for experimental identification of navigator attention in ergatic systems of maritime transport. Bulletin of the University of KaragandaPhysics, 1(97), 58-69. DOI: 10.31489/2020Ph1/58-69

12 Zinchenko, S.M., Nosov, P.S., Mateichuk, V.M., Mamenko, P.P., Popovych, I.S., \& Grosheva, O.O. (2019). Automatic collision avoidance system with multiple targets, including maneuvering ones. Bulletin of the University of Karaganda - Physics, 4(96), 69-79. DOI: 10.31489/2019Ph4/69-79

13 Sims, J.T. (1997, June). Redundancy management software services for Seawolf ship control system. Proceedings of IEEE 27th International Symposium on Fault Tolerant Computing. DOI: 10.1109/FTCS.1997.614114. 
14 Jacobellis, G., Gandhi, F., \& Floros, M. (2019). Using Control Redundancy for Power and Vibration Reduction on a Coaxial Rotor Helicopter at High Speeds. Journal of the American Helicopter Society, 64(3), 1-15. DOI: 10.4050/JAHS.64.032008

15 Mohammadi, A., \& Ramezani, A. (2020). An Active Actuator Fault-Tolerant Control of a Quadrotor Based on Analytical Redundancy Relations. Iranian journal of science and technology - transactions of electrical engineering, 44, 1069-1079. DOI: $10.1007 / \mathrm{s} 40998-019-00292-6$

16 Tarun, K.P., \& Nilanjan, S. (2001). Fault-tolerant control of an autonomous underwater vehicle under thruster redundancy. Robotics and Autonomous Systems, 34(1), 39-52.

17 Zemlyakov, A.S. (2001). Upravlenie uhlovym polozheniem kosmicheskoho apparata s izbytochnoi strukturoi hirodinov [Controlling the angular position of a spacecraft with a redundant gyrodine structure]. Vestnik Kazanskoho hosudarstvennoho tekhnicheskoho universiteta imeni A.N. Tupoleva - Bulletin of Kazan State Tecnical University named after A.N. Tupolev, 4, 56-62 [in Russian].

18 Lebedev, D.V. (2008). Momentum unloading excessive reaction-wheel system of a spacecraft. Journal of Computer and Systems Sciences International, 47(4), 613-620.

19 Wenxiang, G., Qing, T., Jin, Y., \& Yaru, Y. (2020). Automatic motion planning for complex welding problems by considering angular redundancy. Robotics and Computer-Integrated Manufacturing, 62. DOI: 10.1016/j.rcim.2019.101862

20 Zinchenko, S.M., Nosov, P.S., Mamenko, P.P., Grosheva, O.O., \& Matejchuk, V.M. (2019, May). Control redundancy as a quantitative measure of ship maneuverability. Proceedings from Advanced Information and Innovative Technologies for Transport (MINT-2019): XII International Scientific and Practical Conference. (pp. 97-99). Kherson State Maritime Academy, Kherson, Ukraine. 